\title{
An analysis of pro-vaccine and anti- vaccine information on social networks and the internet: Visual and emotional patterns
}

\author{
Ubaldo Cuesta-Cambra; Luz Martínez-Martínez; José-Ignacio Niño-González
}

Nota: Este artículo se puede leer en español en:

http://www.elprofesionaldelainformacion.com/contenidos/2019/mar/04_es.pdf

How to cite this article:

Cuesta-Cambra, Ubaldo; Martínez-Martínez, Luz; Niño-González, José-Ignacio (2019). “An analysis of pro-vaccine and anti-vaccine information on social networks and the internet: Visual and emotional patterns". El profesional de la información, v. 28, n. 2, e280217.

https://doi.org/10.3145/epi.2019.mar.17

Article received on November 10, 2018 Approved on February 25, 2019

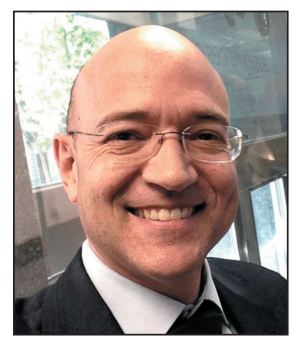

Ubaldo Cuesta-Cambra $\square$ https://orcid.org/0000-0001-7023-7132

Universidad Complutense de Madrid Facultad de Ciencias de la Información Av. Complutense, 3. 28049 Madrid, Spain ucuestac@ucm.es

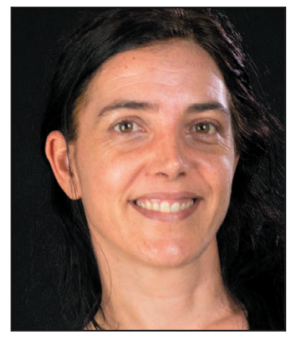

Luz Martínez-Martínez http://orcid.org/0000-0001-8582-724X

Universidad Rey Juan Carlos

Facultad de Ciencias de la Comunicación Camino del Molino, s/n. 28943 Fuenlabrada (Madrid), Spain luz.martinez@urjc.es

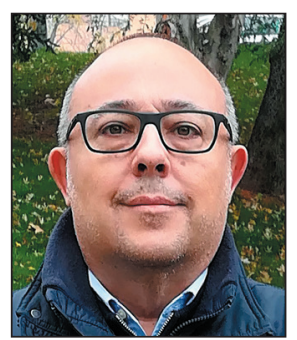

\section{José-Ignacio Niño-González} http://orcid.org/0000-0001-6940-2399

Universidad Complutense de Madrid Facultad de Ciencias de la Información Av. Complutense, 3. 28049, Madrid, Spain josenino@ucm.es

\begin{abstract}
The communication of information about vaccines and anti-vaccines is analyzed through the monitoring of issuers, news sites, groups, and messages in social networks. We also investigate the effects of information on people's attention, emotion, and engagement, which were analyzed using eye tracking, galvanic skin response (GSR) and facial expression methods. Results: the flow of communication was not constant, both in the press and on web sites (376 news in 2015, 74 in 2016, 69 in 2017 and, 268 in 2018); posts were informative and neutral; and 80\% came from non-professional sources (only $17 \%$ were written by a journalist and $3 \%$ by a health specialist). On social networks, anti-vaccine Facebook messages and groups were identified, and a mapping of influencers is presented. Analysis of the temporal evolution (years 2015 to 2018) of communicative flows showed that anti-vaccine posts decreased. Gender differences appeared in the visual exploration of information sources and in the provoked emotion responses (GSR and facial expression). In pro-vaccine pages women looked at the headline first, while men looked at the photograph. Emotional responses and engagement did not show differences between anti-vaccine and pro-vaccine web sites. No differences were found in the emotion provoked (GSR) between both website types: anti-vaccination persuasion occurred via cognitive, not emotional, methods by using heuristics (e.g., conspiracy theories). Emotional responses and engagement did not show differences between pro-vaccine and anti-vaccine web sites.
\end{abstract}




\section{Keywords}

Vaccines; Internet; Social networks; Public health; Anti-vaccines; Anti-vaxxers; Health information; Health communication; Influencers; Eye-tracking; Facial expression; Galvanic skin response; GSR.

\section{Introduction}

In recent years, education about vaccines has become a public health problem. The data show a decrease in the vaccination of children against certain viruses, and the outbreak of diseases already eradicated; this includes low vaccination against seasonal influenza ( $E C D C, 2015 b ; 2018)$. The main causes of this reluctance are related to:

- effects of comments on the safety of the vaccine;

- lack of adequate information;

- perception that vaccines are not effective or necessary (ECDC, 2015a).

The perception that vaccines are not safe has become increasingly globalized, especially in Europe. Spain is in tenth place in Europe in the acceptance of vaccines, where a percentage of the population perceive them as not important, not safe, and ineffective (Larson et al., 2016). Faced with this situation, communication and health specialists work on strategies to counter fears and myths regarding vaccines, usually through evidencing scientific facts contrary to misinformation.

However, anti-vaccination attitudes are not only based on the scarcity of information or the scientific communication deficit, which implies a lack of understanding of this by the users. Individuals with anti-vaccine attitudes tend to question scientific evidence, and their attitudes are not due to lack of education or information (Larson et al., 2014; Jones et al., 2012). Recent studies have shown that exposure to correct information about vaccines did not have a significant positive effect (Horne et al., 2015). This phenomenon can be explained because individuals do not always form their opinion based on evidences. The perspective of motivated reasoning (Browne et al., 2015) states that subjects develop an attitude based on emotions, which then motivates them to seek information and communicative flows that support their opinions. This means that individuals, for example with an anti-vaccination attitude, consume and value more types of information that reinforces their convictions. Simultaneously, they reject information that may discredit what they hold to be true, regardless of its scientific veracity.

Likewise, it has been found that some pro-vaccine campaigns or interventions can initiate the boomerang effect, causing an opposite result to the one they sought to achieve, especially in those campaigns aimed at modifying the attitudes and behaviors of people who express anti-vaccination opinions and behaviors. Betsch and Sachse (2013) verified that the use of extreme messages denying risks of vaccination instead resulted in a greater perception of the risk of vaccination. This phenomenon often occurs in interventions in other areas such as anti-alcohol (Snyder; Blood, 1992), anti-violence (Cárdaba et al., 2016), anti-tobacco (Erceg-Hurn; Steed, 2011), or anti-marijuana campaigns (Kang; Cappella; Fishbein, 2009).

Finally, another important factor in opinion formation and subsequent behaviors towards vaccines is the way in which the subject, or the framing effect of the offered information is approached (Tversky; Kahneman, 1981; Kuo; Hsu; Day, 2009). Take for example, the visibility and type of vaccines mentioned. This framing (Entman, 1993; Scheufele, 1999) not only dictates the relevance and importance of social issues by setting the public agenda (McCombs; Shaw, 1972) but also affects the cognitive responses of the subjects as well as their attitudes and beliefs about the issues discussed (Price; Tewksbury; Powers, 1997; Aday, 2006; Keum et al., 2005).

Therefore, one of the biggest problems is to overcome the reluctance to vaccination (which causes the delay of application or its total rejection despite the availability of services), for which effective vaccination education campaigns are necessary (ECDC, 2015a). To this end, the World Health Organization (WHO, 2014) identifies the need for better monitoring of confidence in vaccines and the need for better communication with citizens.

From the field of public health, the importance of communication channels, such as the Internet and social networks, as generators of public opinion and healthy behaviors cannot be overstated (Dubé et al., 2016; Verger et al., 2015; Onnela et al., 2016). The issue of vaccination is especially sensitive to this phenomenon due to the large amount of available information and discussion, and the increasing tendency of citizens to seek and share this information. Currently, a high percentage of the population looks for health information on the Internet (Dannetun et al., 2005; Peña-Lillo-Arayasa, 2016), making their
In terms of the communication of health information, the influence of the internet and social networks on public opinion and healthy behaviors cannot be understated 
decisions accordingly (Chanel et al., 2011; Downs; De-Bruni; Fischhoff, 2008). In addition, interaction and discussion through social networks mean that the information received from search engines or certain persons is perceived as reliable information without being more rigorously researched (Witteman; Zikmund-Fisher, 2012) or even false, as fake news, comes to be considered true, impacting the increase of unvaccinated individuals (Salathé; Bonhoeffer, 2008; Liu et al., 2015; CDC, 2013). This effect can be noted in the after effects of the work of Andrew Wakefield, who linked measles, mumps and rubella vaccines with autism, which instigated a negative effect on vaccination rates (Wakefield, 1998).

In Kortum, Edward, and Richards-Kortum's (2008) study on the perception of information received from search engines, they found that $59 \%$ of the participants who searched the internet using the terms "safe vaccine" and "dangerous vaccine" perceived it as accurate information, despite the fact that more than half of the websites were not accurate, and $53 \%$ of the subjects showed misconceptions of the vaccines after the study. In another study evaluating trust between Facebook friends, Liu and Brown (2014) considered friends as opinion leaders or DOLs (digital opinion leaders), whose followers found information that they shared to be sincerer and more trustworthy (Turcotte et al., 2015). Noteworthy is the influence of particular profiles in social networks, as associated to the number of followers and publications that further enhance their visibility (Veale et al., 2015; Rus; Cameron, 2016; Wang et al., 2017). The nature of the Web allows any user to publish information or comment sporadically without becoming a reference or an opinion leader. Another feature of the Web is the transience of the profiles and information managers that are not perpetuated over time. Therefore, factors such as the number of publications and followers over time allow the identification and measurement of the influence of those profiles that actively and continuously publish information on vaccines, gaining them a kind of "specialized" status in front of the users familiar with their posts. This regular activity is important in digital health interventions, which informs and engages the audience, promoting attitudinal and behavioral changes (Preece; Shneiderman, 2009; Syred et al., 2014; Wong; Merchant; Moreno, 2014).

Another risk factor is the appearance of the "anti-vaccine" phenomenon (Nasir, 2000; Zimmerman et al., 2005). This movement disseminates information contrary to that offered by public health and experts. For example, there are anti-vaccine groups, in social networks such as Facebook, focused almost exclusively on women, such as papillomavirus (Martínez-Martínez; Cuesta-Cambra, 2018). The so-called "anti-vaxxers" on these platforms are quite active, and have some influence on the general public, causing confusion and disinformation regarding vaccinations and their side effects (Wilson; Atkinson; Deeks, 2014). Although several studies on the dissemination of content on social networks have shown a greater publication of positive content (Love et al., 2013; Ache; Wallace, 2008), social networks (such as forums or Facebook groups) can also be used to transmit doubts and concerns (Keelan et al., 2010) and tend mostly to focus on the risks of vaccines, rather than on benefits (Huesch; Ver-Steeg; Galstyan, 2013; Seeman; Ing; Rizo, 2010).

Keelan et al.'s (2010) study on the debate of the human papilloma virus (HPV) vaccine, found that publications within anti-vaccine spaces focused on criticisms of parents' authority to decide for their children, or on pharmaceutical interests. This study also showed that men are more likely to adopt and publish an anti-vaccine posture. In another study on anti-vaccination discourse on the Internet (Kata, 2012) it was found that these movements avoid negative concepts such as an "anti-vaccine" stance. By defining themselves as a "movement of pro-safe vaccines", they intend to transmit the image that they do not entirely condemn vaccines, and instead favor "safe" vaccines, criticizing exclusively those that are "unnatural or toxic". This type of stance based on emotion, fear, and worry motivates the limbic resonance of the subjects, by sharing emotional states, awakening empathy, and favoring emotional involvement or engagement (Lewis; Amini; Lannon, 2001; Millon et al., 2003). These frames based on sentiment define problems, diagnose their causes, make moral judgments, and suggest solutions (Entman, 1993). The nature of the Internet and social networks allows the dissemination of information through small publications that do not leave room for an explanation of context, thus facilitating the decontextualization of facts and an increase in impulsive behaviors and opinion-forming.

Information about vaccines on the Internet and social networks can be effective, ineffective, or even counterproductive (Nyhan et al., 2014). Hence the importance of knowing the type and quality of the information offered, and evaluating the variables related to

- the issuer (type of source and channel),

- the message (content and pro/anti-vaccine inclination), and

- the recipient (informative preferences),

determining factors in the formation of opinion and in a subsequent conduct towards vaccines (Tversky; Kahneman, 1981; Kuo; Hsu; Day, 2009).

To be able to analyze in-depth the movement towards pro- and anti-vaccine viewpoints, it is of great interest to resort to the methodology of Social Network Analysis (SNA) (Lozares, 1996). This type of analysis allows the collection of data through web scraping techniques (Williams et al., 2015), enabling the monitoring and analysis of social networks and helping to identify those agents or nodes (Hansen; Shneiderman; Smith, 2010) that center around vaccines. In this way, 
opinion leaders can be detected- being those who direct the conversation, as well as intrinsic characteristics such as the number of relationships established. In the same way, possible clusters are detected (Anderberg, 1973) that allow the identification of groups within the network of nodes, based on different variables (Clauset; Newman; Moore, 2004) such as the topics of interest, or frames (specific diseases or vaccines). It is also possible to measure emotional weight and popularity of different groups within the network and between nodes.

These implicit variables such as emotion and engagement can be analyzed by neuro-communication techniques that allow the registration of the psychological or automatic responses of the subjects against the pro- and anti-vaccine information:

- techniques such as eye tracking allow the identification of the visual path (gaze path), the interest on the information (heatmaps), and the commitment caused (Duchowski, 2013; Añaños-Carrasco, 2015);

- the visual selection and the gaze path allow us to study the effectiveness of the information and the way in which the subjects structure it (Plassmann; Ramsøy; Milosavljevic, 2012);

- facial reading of emotions or facial expressions enables recording emotional states of individuals through observable gestures like a smile or micro-muscular changes such as contractions associated with certain reactions, indicator of the positive or negative emotional responses of individuals (measure of the valence);

- the dermo electric response or galvanic skin response (GSR) records the electrodermal activity or conductance of the skin which can be affected by emotional arousal. The triangulation of the indicators will enable us to evaluate the degree of emotion, if this is positive or negative, and the engagement caused by both types of information on vaccines, which will also allow a greater understanding of the boomerang effect in pro-vaccine interventions.

\section{Objectives}

The objective of the research is to analyze the type of information on vaccines that exists on the internet: sources, references, themes, and tone (positive, negative, or neutral).

Also, it is about analyzing the flows of communication in social networks, where there is a high dissemination of information but also of misinformation through anti-vaccine actors and non-corroborated news or fake news. Given the high flow of information within these networks, it was decided to analyze the networks that, according to previous works (Cuesta-Cambra; Cuesta-Díaz; Gaspar-Herrero, 2016; Cuesta-Cambra, 2013) present more relevance in this context: Facebook and Twitter.

The analysis and coding of this information over a long period of time allows us to identify the informative referents or DOLs (digital opinion leaders) in pro- and anti-vaccine groups, to determine the frames that are used and the "limbic resonances" (emotional arousal or engagement) that they cause. This engagement can be evaluated through the neuromarketing techniques described above (eye-tracking, facial expression, and GSR), which make possible the analysis of the implicit sentiment (psychophysiological responses) in the subjects, and also through the identification of different visual patterns (eye-tracking) (Cuesta-Cambra; Martínez-Martínez; Niño-González, 2018a).

To study these objectives, the following research questions (RQ) were raised:

RQ1: What is the speech that is being broadcast by digital media, either from official sources, or from associations or individuals, about vaccines on the Internet? More specifically: What are the most relevant issues, the sources and the tone, and treatment of the information?

RQ2: What are the most relevant pro- and anti-vaccine tendencies on the internet and on the social network Facebook?

RQ3: What are the most relevant DOLs for and against vaccines on Twitter and what communication flows do they disseminate?

RQ4: Will a diachronic analysis of these information and communication flows of the last four years show evolutions or changes of significant trends?

Given its transversal nature, this RQ4 will be answered in each of the research sections.

RQ5: Are there differences in the way of looking and structuring the information (visual gaze and heatmaps) between web sites or information that fall in the pro- or anti-vaccine camps? In addition, will the gender variable cause differences in these visual patterns, as it happens in other similar works (Cuesta-Cambra; Niño-González; Rodríguez-Terceño, 2017)?

Previous research (Kata, 2012; Keelan et al., 2010) shows that anti-vaccine information seems to use more emotional frames than information offered by specialists, which is more rational and based on scientific evidence. As we have explained, through the neuro-communication techniques such as the galvanic skin response (GSR) and the facial expression technique (analysis of minimal facial muscle movements) the following factors can be analyzed:

- emotion: positive or negative valence, and its intensity;

- engagement: commitment or interest shown, and its intensity. 
Hence, eye-tracking can evaluate:

- visual attention: "total time" dedicated to the image;

- visual route through the screen of the mobile or computer.

Therefore, and considering the previous works (Cuesta-Cambra; Martínez-Martínez; Niño-González, 2018a; Duchowski, 2013; Plassmann; Ramsøy; Milosavljevic, 2012), the following hypothesis is presented:

HP1: The anti-vaccine messages use more emotional content and format than the pro-vaccine, causing greater implicit sentiment evaluated by means of GSR and facial expression.

\section{Method}

A descriptive analysis was developed for publications about vaccines on the sites (websites, blogs, digital press) and social networks Facebook and Twitter, in the months of April 2015, 2016, 2017, and 2018. In order to obtain data, Google Search and specialized search engines extensively checked of Facebook and Twitter were used (Madurga, 2018; Cuesta-Cambra; Martínez-Martínez; Niño-González, 2018b) with the values "vaccine" and "vaccines".

All the stimuli, both the websites and platforms, and social networks, were coded using templates used in previous research (Chen et al., 2015; Hale et al., 2014; Cuesta-Cambra; Gaspar-Herrero, 2014) and analyzed according to:

- source and channel;

- number of publications;

- tone of the information towards the vaccine;

- type of profiles;

- popularity,

the same period of time in those four years.

Two specialists in digital communication developed the coding for the project. They registered data in two parts: one being from the websites to analyze the most informative part (media, sources, topics, coverage) and the other being from the Facebook and Twitter platforms to analyze communicative flows (profiles, publication, and DOLs). The entire procedure was collected in a structured "codebook".

For the analysis of the implicit variables carried out by means of neuro-communication techniques, a sample of 18 subjects voluntary participated, chosen randomly among students and administration and services staff of the Universidad Complutense de Madrid. The following variables were evaluated:

- emotion

- attention

- visual path

- engagement

The study took place in the Neurolabcenter UCM using IMotions software system for the processing of the indicators. http://www.neurolabcenter.com https://imotions.com

The subjects were exposed to two screenshots of two websites with opposite positions towards vaccines (Redacción médica, pro-vaccine, and Buscando la verdad, anti-vaccine). Both images show a web portal with an upper header, a news with headline and image, and a module in the shape of a banner for the latest news. These pages were taken as examples since in the previous monitoring analysis they were identified as representative of 2018 websites about vaccines due to their frequency of similar publications and type of content.

The sensors used to obtain data were: Shimmer for the GSR registration, Tobii Eye Tracking for the eye-tracking, and a high definition camera together with the Affectiva software for facial recognition. The subjects were instructed to "read the web on the screen in a natural way and to take the appropriate time needed". During viewing, the biometric variables described were automatically recorded by the computer system. The field work was developed during the months of October and November 2018 and all the research followed the protocols of the Research Ethics Committee of the Communication Theories and Analysis Department of the Faculty of Information Sciences of the Universidad Complutense de Madrid.

\section{Results}

Research question 1 (RQ1): There is a decrease in the amount of news about vaccines in recent years and some recovery in 2018 (figure 1). 376 news stories were found in 2015, 74 in 2016, 69 in 2017, and 268 in 2018. During these periods of time, the most popular themes
In 2018 , only $17 \%$ of the websites that issued health posts had a journalist and only $3 \%$ had a health specialist 
were those referring to "General information", "Public health policy", "Vaccine research", "Effectiveness", "New outbreaks", "Pharmaceuticals", "Anti-vaccines", "Congresses/actions", and "Side effects" (Figure 1).

We verified that the interest in certain topics had been maintained, especially in general information, research on vaccines, and public health policies. The latter, however, had decreased in interest, especially in 2018. Nevertheless, we identified a growing trend in general interest for the efficacy of vaccines.

According to the type of vaccines covered in the news, we observed some that maintained interest over time, such as those related to influenza, chickenpox, HPV (human papillomavirus), meningitis, HIV, measles, cancer, or whooping cough. These are vaccination campaigns, research, and vaccine efficacy.

We found a large number of news items that did not specify a vaccine or disease in particular. In "Others" we find isolated news about vaccines focused on smallpox, Alzheimer's, or pneumonia (table 1)

In relation to media with news about vaccines, the greatest concentration was found in digital press channels, and to a lesser extent on websites.

The data for 2018 show that of these websites ( $n=65$; $24 \%$ ), only $17 \%$ of the emitter or source are journalists, while $3 \%$ are health specialists. This reveals that the vast majority $(80 \%)$ of the information flow on the Internet is not in the hands of health specialists.

Within the digital press, differences were found among the media outlets regarding the inclusion of news about vaccines. Table 2 shows the relationship of the 10 media sources with the most publications in 2015 and 2018; in 2017 and in 2016, no media published more than two news items focused on vaccines. Only La vanguardia, Redacción médica, Acta sanitaria, and $A B C$ were part of the top ten media both years, appearing as informative referents, although their publication lowered in 2018.

Research question 2 (RQ2): We present the results of this RQ2 on the most relevant pro- and anti- vaccine trends in two sections: the first section regarding the sites and the second section regarding Facebook.

1) Websites: the data show a tendency to maintain a mostly neutral tone during the four years, followed by news with a pro-vaccine stance, the latter with an increase in 2018. Those of a negative nature represent a small percentage of publications with an evaluation rate between $2-4 \%$, decreasing in recent years (figure 2 ).

A specific analysis of the anti-vaccination messages over the last four years was made to analyze the diachronic evolution (table 3). Differences were noted in the emitters of these messages during the time period analyzed, only the Miguel Jara and DSalud sources are present two years.

Table 1. List of vaccines with greater presence in sites by year

\begin{tabular}{|l|c|c|c|c|}
\cline { 2 - 5 } \multicolumn{1}{c|}{} & $\mathbf{2 0 1 5}$ & $\mathbf{2 0 1 6}$ & $\mathbf{2 0 1 7}$ & $\mathbf{2 0 1 8}$ \\
\hline Vaccine & $\%$ & $\%$ & $\%$ & $\%$ \\
\hline Influenza & 11 & 1 & 1 & 3 \\
\hline Ebola & 10 & - & - & 2 \\
\hline Chickenpox & 10 & 14 & 1 & 1 \\
\hline HIV & 9 & - & 1 & 1 \\
\hline Pneumococcus & 7 & - & - & - \\
\hline Measles & 7 & - & 1 & 3 \\
\hline HPV & 6 & 16 & 4 & 6 \\
\hline Meningitis & 4 & 7 & 28 & 13 \\
\hline Cancer & 3 & - & 6 & 4 \\
\hline Whooping cough & - & 5 & 12 & 1 \\
\hline Without type & 17 & 7 & 3 & 34 \\
\hline Others & 16 & 50 & 43 & 32 \\
\hline
\end{tabular}

Table 2. Comparison of media with more news in 2015 and 2018

\begin{tabular}{|l|c|l|c|}
\hline \multicolumn{2}{|c|}{2015} & \multicolumn{2}{c|}{2018} \\
\hline Media & $\%$ & \multicolumn{1}{c|}{ Media } & $\%$ \\
\hline Infosalud & 7 & La vanguardia & 6 \\
\hline Agenda Europa press & 6 & La razón & 5 \\
\hline Teinteresa & 5 & Con salud & 3 \\
\hline Redacción médica & 4 & Redacción médica & 3 \\
\hline Acta sanitaria & 4 & Acta sanitaria & 3 \\
\hline elEconomista & 4 & 20 minutos & 2 \\
\hline Gaceta médica & 4 & ABC & 2 \\
\hline Diario siglo XXI & 3 & Isanidad & 2 \\
\hline ABC & 2 & La voz de Galicia & 2 \\
\hline Others & 55 & Others & 69 \\
\hline
\end{tabular}


2) Facebook groups in Spanish: there had to be a minimum of 10 members in a group to be included in the analysis. We selected the 20 most influential groups and the 20 most influential pages in 2015 and 2018. The 20 groups with the most followers accounted for a total of 12,902 members in 2015 compared to 19,591 in 2018 (table 4). In both cases, we see that the majority of members are concentrated in a few pages.

Subsequently, we made comparative analysis of the popular pages that appeared in 2015 that did not appear in 2018, proving that many of them no longer existed: No a las vacunas forzadas, No a la va-

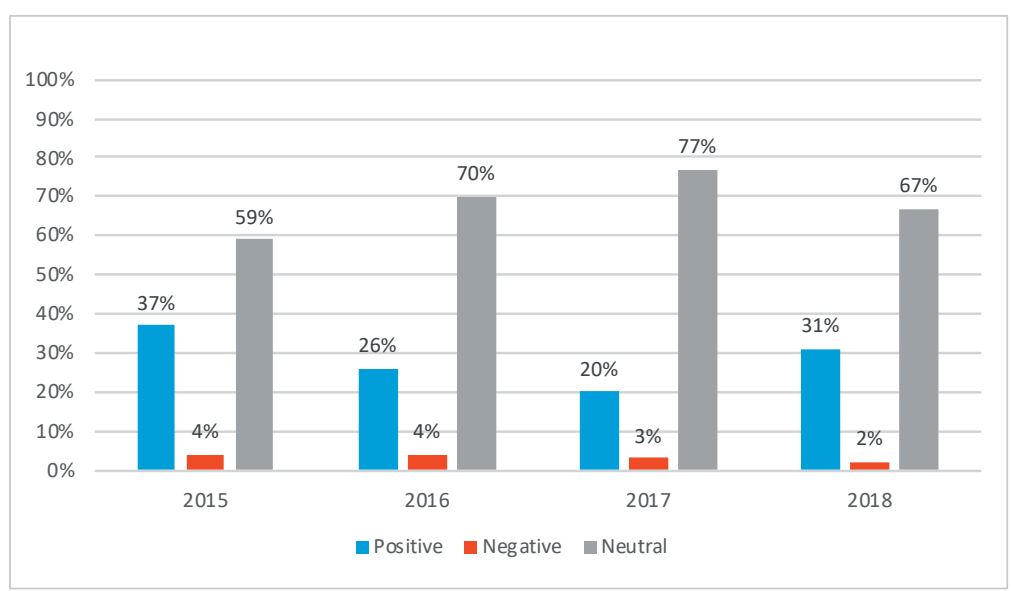

Figure 2. Tone of news publications

Table 3. Comparison of media with anti-vaccine messages

\begin{tabular}{|c|c|c|c|c|c|c|c|c|c|c|c|}
\hline \multicolumn{3}{|l|}{2015} & \multicolumn{3}{|l|}{2016} & \multicolumn{3}{|c|}{2017} & \multicolumn{3}{|l|}{2018} \\
\hline Media & Ms & $\%$ & Media & Ms & $\%$ & Media & Ms & $\%$ & Media & Ms & $\%$ \\
\hline Miguel Jara & 8 & 34 & DSalud & 1 & 33 & DSalud & 1 & 50 & Buscando la verdad & 2 & 40 \\
\hline Quitar el velo & 8 & 34 & Desmontando a la Pili & 1 & 33 & Miguel Jara & 1 & 50 & Maestro viejof & 1 & 20 \\
\hline Detengan la vacuna & 2 & 8 & Real fitness & 1 & 33 & & & & Periodista digital & 1 & 20 \\
\hline Apocalipsis y actualidad & 2 & 8 & & & & & & & Toluna & 1 & 20 \\
\hline Periodistas-es.com & 1 & 4 & & & & & & & & & \\
\hline El confidencial & 1 & 4 & & & & & & & & & \\
\hline Acta sanitaria & 1 & 4 & & & & & & & & & \\
\hline La matrix holográfica & 1 & 4 & & & & & & & & & \\
\hline
\end{tabular}

Table 4. Ranking of 15 top Facebook groups in Spanish about vaccines

\begin{tabular}{|c|c|c|c|}
\hline \multicolumn{2}{|l|}{2015} & \multicolumn{2}{|l|}{2018} \\
\hline Group & Members & Group & Members \\
\hline Movimiento antivacunación & 5,679 & Asociación de afectadas por la vacuna del papiloma & 4,229 \\
\hline Asociación de afectadas por la vacuna del papilloma & 2,831 & Vacunas y desparasitaciones peluditos queretaro & 2,659 \\
\hline Vacuna ya & 1,400 & Afectados por las vacunas & 1,815 \\
\hline Por qué decimos No a la vacunación & 848 & Vacunaya & 1,373 \\
\hline No a las vacunas con timerosal & 496 & Alergia y vacunas & 1,195 \\
\hline No a la vacuna & 467 & Vacunas sin timerosal en Argentina & 860 \\
\hline No a la vacunación & 401 & No a las vacunas con timerosal & 774 \\
\hline No a las vacunas forzadas & 170 & Controversias de la vacuna contra el HPV & 687 \\
\hline No más vacunas con mercurio en chile & 142 & Elijo vivir sin vacunas - Uruguay & 682 \\
\hline No a las vacunas & 127 & No a las vacunas. No envenenes a tus hijos & 658 \\
\hline $\begin{array}{l}\text { Chantas, vacunas y caras de raja que no pagan pensión } \\
\text { de alimentos mode on }\end{array}$ & 82 & Vacunas Sayula & 623 \\
\hline $\begin{array}{l}\text { Asociación de afectadas por la vacuna del papiloma. } \\
\text { Colombia }\end{array}$ & 51 & Información sobre vacunas sin censura & 311 \\
\hline Antivacunas & 49 & No a la vacunación. No to vaccines & 285 \\
\hline ¡No más vacunas del VPH en Colombia! & 48 & Solo vacunas escasas Valencia Edo Carabobo & 268 \\
\hline Las vacunas nos matan & 28 & No a las vacunas & 259 \\
\hline No a la vacunación de nuestras niñas & 28 & Asociación de afectadas por la vacuna del papiloma. Colombia & 250 \\
\hline Los antivacunas & 22 & Por qué decimos no a la vacunación & 250 \\
\hline Vacunas otra vez noiiii & 12 & Científicos provacunas & 190 \\
\hline No a las vacunas de mierda & 11 & Vacunas, Mms-Cds, Salud Alfredo Daniel Ortiz & 158 \\
\hline No queremos vacunas!!! & 10 & Movimiento alerta vacuna Costa Rica & 138 \\
\hline
\end{tabular}


cuna, and No más vacunas con Mercurio en Chile. We detected where the number of members had decreased in 2018: Asociación de afectadas por la vacuna del papiloma, Vacuna ya, or Los antivacunas).

In 2015 most of the groups showed an anti-vaccine position, only the Vacuna group was already in favor. This is an active Spanish group that posted with some frequency and with high "like" rates (range between 10-40 usually), but has recently decreased the number of members and shows less activity.

In the groups of 2018 , it was found that the position versus vaccines had greater diversity, finding $60 \%$ against, $30 \%$ in favor, and $10 \%$ with a neutral tone.

For the analysis of the Facebook pages the same criteria for the groups was followed, collecting the 20 most popular ones - (those with the greatest number of "likes"). In April 2015, the top 20 pages comprised a total of 57,607 "likes", of which $60 \%$ were in favor of vaccines $(34,387)$, while $40 \%$ were against $(23,220)$. In April 2018 , the 20 main pages collected 225,083 "likes", of which $56 \%$ were in favor $(125,199), 21 \%(46,782)$ were against, and $23 \%$ were neutral $(53,102)$. As was the case with the groups, there are differences between the sources of the pages in 2015 and in 2018, finding only three cases (Miguel Jara, Quitar el velo, and Programa de vacunación de Puerto Rico) that maintained their popularity by doubling the number of "likes" in the last three years.

Of the 20 top pages, in 2015 only 5 were Spanish ( 2 against and 3 in favor), with a total of 11,550 "likes" and with a trend different from the general one, where $68 \%(7,901$ "likes") were anti-vaccine and $32 \%$ in favor $(3,649)$. The largest number was collected by Miguel Jara's page with 7,190 "likes". In 2018, this trend was maintained with 5 pages of Spanish origin, 3 of which were in favor (Comité Asesor de Vacunas de la Asociación Española de Pediatría (CAV-AEP), Hablemos de vacunas, and Gdt en vacunas) and represented $39 \%$ of the "likes" $(9,014)$, while 2 were against (Miguel Jara and No a la vacuna: España) with $61 \%$ of "likes" $(13,980)$. We would like to underline that Miguel Jara's page collected the vast majority of "likes" $(13,000)$.

Research question 3 (RQ3): To know the most relevant communication proand anti-vaccine flows and DOLs (digital opinion leaders) on Twitter, a daily monitoring of the platform was developed using the keyword "vaccine/s" (in Spanish), which offered 36,000 tweets in 2015 and 1,982,691 in 2018. Tweets and profiles were coded using "personal tweets" and "tweets on animal vaccines" as exclusion criteria.

Finally, the most popular and active profiles for and against vaccines were analyzed in order to find out the DOLs of the flows pro- and anti-vaccine (figure 3 ).

For the case of the pro-vaccine influencers, we made a comparative ranking of 2015 and 2018 (table 5). In 2015, these profiles collected 51,119 followers and 1,896 tweets published, while in April 2018 there were 215,391 followers and

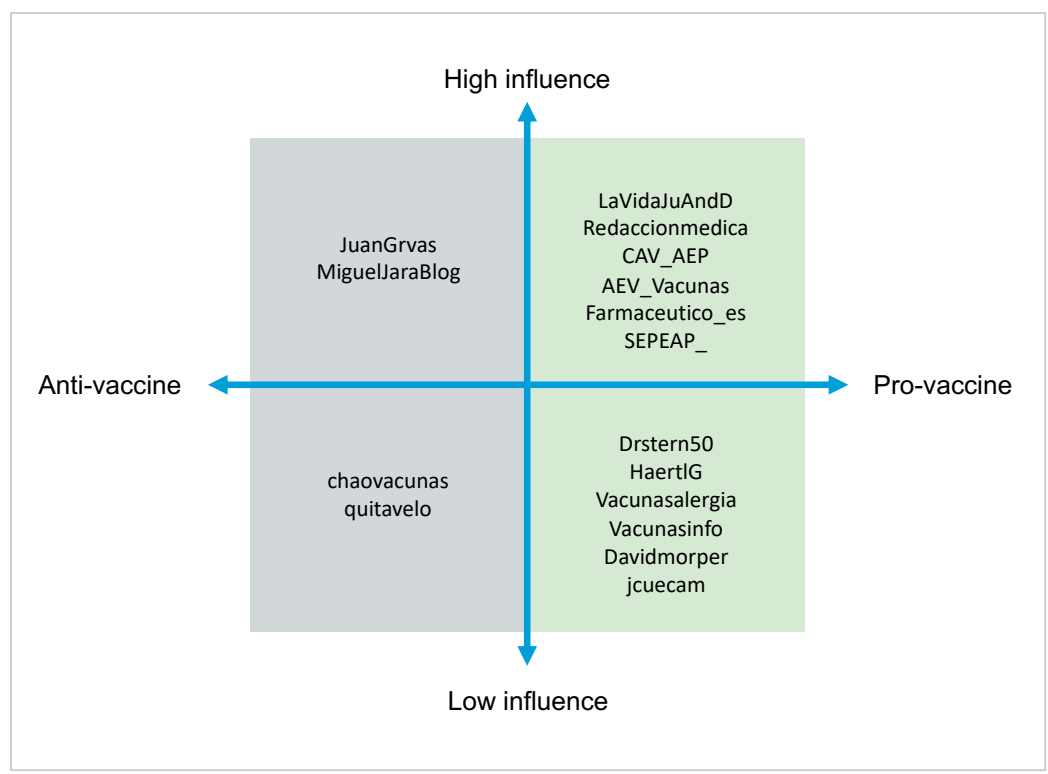

Figure 3. Influencers of 2018 classified by degree of influence and trend

Table 5. Comparative top 12 influencers in favor of vaccines on Spanish Twitter 2015 and 2018

\begin{tabular}{|l|c|r|l|r|r|}
\hline \multicolumn{4}{|c|}{2015} & \multicolumn{4}{c|}{2018} \\
\hline Account & Followers & Tweets & \multicolumn{1}{|c|}{ Account } & Followers & Tweets \\
\hline @redaccionmedica & 29,368 & 606 & @LaVidaJuAndD & 104,400 & 15,000 \\
\hline @CAV_AEP & 4,670 & 49 & @redaccionmedica & 62,100 & 167,000 \\
\hline @AEV_Vacunas & 3,654 & 73 & @CAV_AEP & 11,000 & 6,236 \\
\hline @HaertIG & 2,915 & 32 & @AEV_Vacunas & 7,846 & 7,923 \\
\hline @Vacunasalergia & 2,641 & 11 & @Farmaceutico_es & 7,753 & 57,600 \\
\hline @SEMPSPPH & 2,030 & 71 & @SEPEAP_ & 4,974 & 15,600 \\
\hline @Vacunasinfo & 1,801 & 40 & @drstern50 & 4,073 & 96,030 \\
\hline @PedriatriaBalear & 1,320 & 294 & @HaertIG & 3,995 & 5,850 \\
\hline @SEPEAP_ & 1,241 & 117 & @Vacunasalergia & 3,291 & 1,469 \\
\hline @jcuecam & 1,072 & 433 & @Vacunasinfo & 2,929 & 5,953 \\
\hline @davidmorper & 239 & 19 & @davidmorper & 1,537 & 3,248 \\
\hline @AlsinaMier & 199 & 151 & @jcuecam & 1,493 & 48,700 \\
\hline
\end{tabular}


430,609 tweets. As it happened in other social networks, the sources vary; finding only two (@CAV_AEP and @SEPEAP) pages that have lasted over time. We can see that for some pages, although the number of followers has doubled, the number of publications has grown much more. Despite this, these have lost positions in the ranking by followers. We also found that other accounts such as @ SEMPSPPH and @PedriatriaBalear ceased to exist.

In the case of anti-vaccine influencers, in the 2015 analysis, fewer profiles were found with a relevant number of followers (more than 50). In total these profiles collected 10,000 followers, highlighting the accounts of Juan Gervás (@JuanGrvas) and Miguel de la Jara (@MiguelJaraBlog) that accounted for most of them. Both are very active in publishing tweets, but with few retweets (from 2 to 7). The analysis in 2018 reveals the growing popularity of the profiles, the Juan Gervás account doubled the number of followers and tripled the number of tweets remaining in first place, followed by Miguel de la Jara, who was less active during the last three years, despite going from 4,000 to 6,000 followers (figure 4).

Research question 5 (RQ5): The eye-tracking technique was used to study the differences in the way of looking and structuring information when presented with pro- and anti-vaccine websites/information, and the effect of gender in visual patterns. This technique permits analysis through heatmaps and gaze paths of the subjects facing the stimuli. The heatmaps generated by both pages show the elements that attracted the most attention.

In the case of the pro-vaccine website, the areas with the highest concentration were (figure 5):

1) the headline "Vaccines, $95 \%$ of babies are protected and avoid 30,000 diseases";

2) the body of the news;

3) the face of the girl in the photograph;

4) the latest news.

In the case of the anti-vaccine page, the highest attention was found in:

1) the headline "Dr. Suzanne Humphries 'Vaccines are dangerous and should never be injected into anyone for no reason'";

2 ) the image, specifically the face of the woman who appears.

Other elements such as the syringe and the skull did not receive as much attention (figure 6). We found differences in the attention placed on the header, being very low in the case of anti-vaccine.

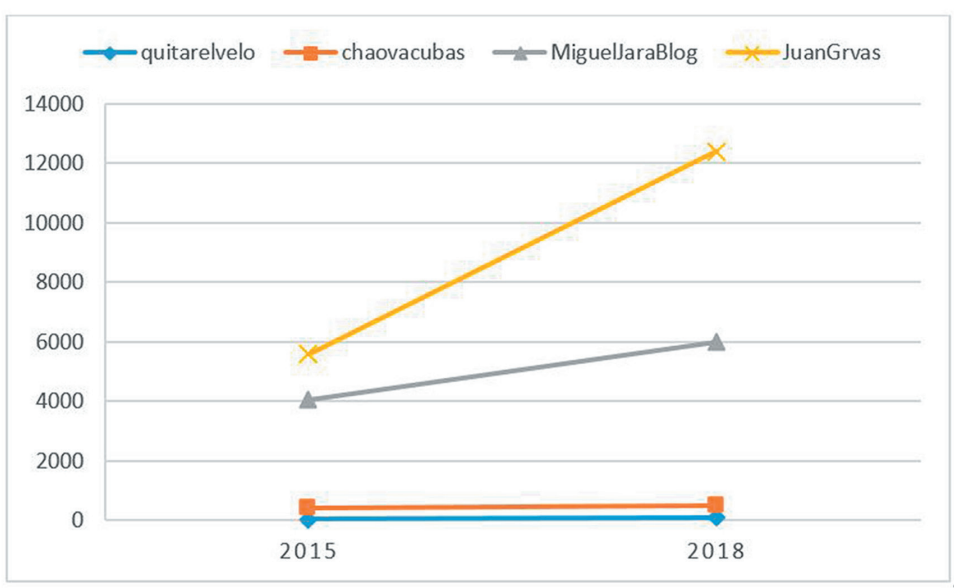

Figure 4. Evolution of anti-vaccine influencers on Twitter

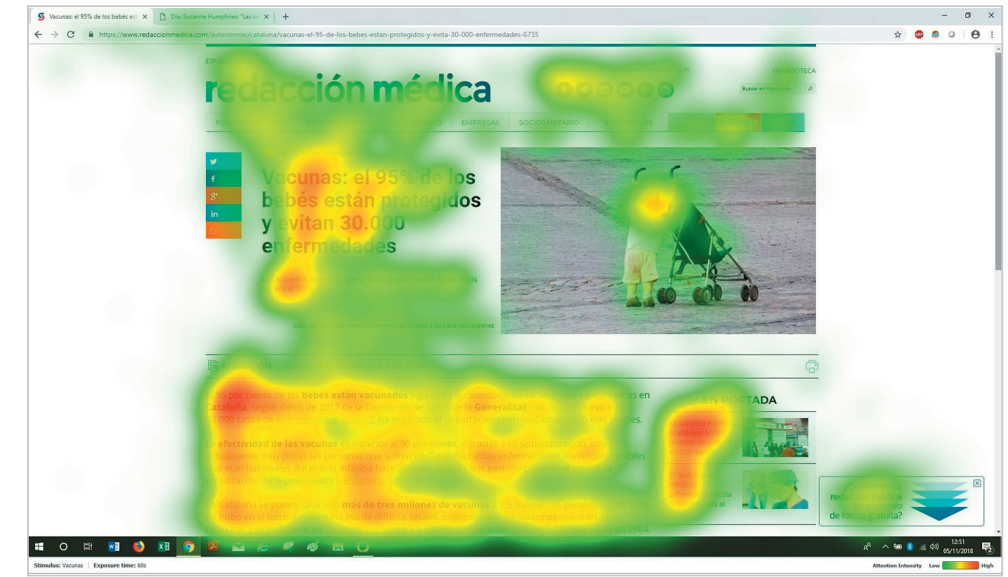

Figure 5. Pro-vaccine heatmap site

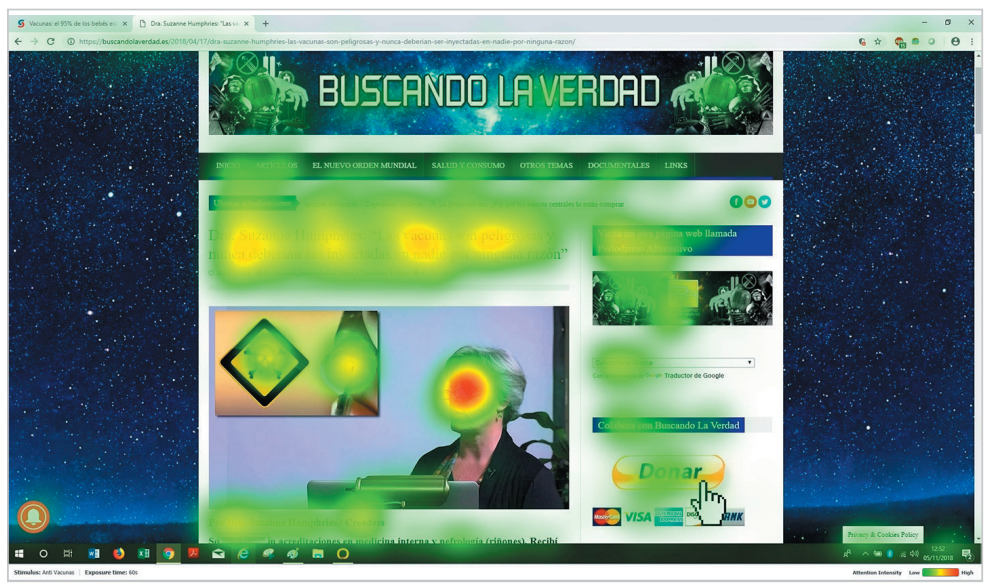

Figure 6. Anti-vaccine heatmap site

The comparison of the visual routes of both pages shows a similar initial pattern: the subjects directed their attention to the headline, then to the header where the name of the page appears, and finally down towards the content. In the case of the anti-vaccine website, the photograph captured the attention sooner than the pro-vaccine page.

The analysis of the Area of Interest shows the differences of attention for both pages. Through the variables: 
- TTF: time that the subject takes to fix the eyesight on the point of interest;

- TS: time the subject spends on the point of interest;

- Ratio: number of subjects that look at the point of interest,

we can observe that the headline of the anti-vaccine page attracted more attention from the subjects (TS 6.2s) than did the pro-vaccine one (TS 3.1s). The subjects on the anti-vaccine page barely paid attention to the header with the name of the site (TS 1.8s) confirming the data obtained from the heatmap.

As it was raised in the research question, differences were identified between the gaze path of men and women.

In the case of the pro-vaccine page, women looked at the headline and then the body of the news, while the men looked at the photograph before the text (figures 7 and 8). In the anti-vaccine page, all subjects looked at the headline first, but women immediately looked at the photos such as the syringe and the skull, while men looked up at the header, leaving these resources to the end (figures 9 and 10).

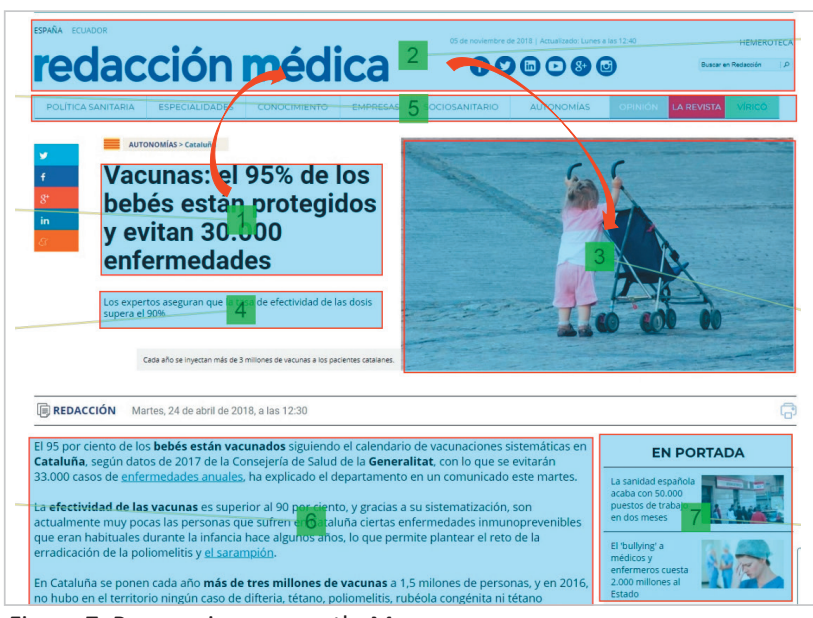

Figure 7. Pro-vaccine gaze path, Men

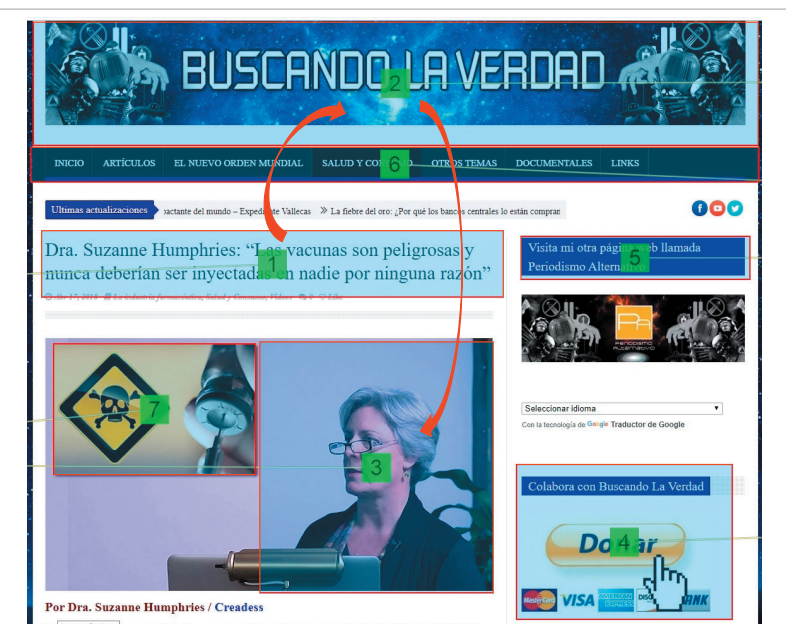

Figure 9. Anti-vaccine gaze path, Men

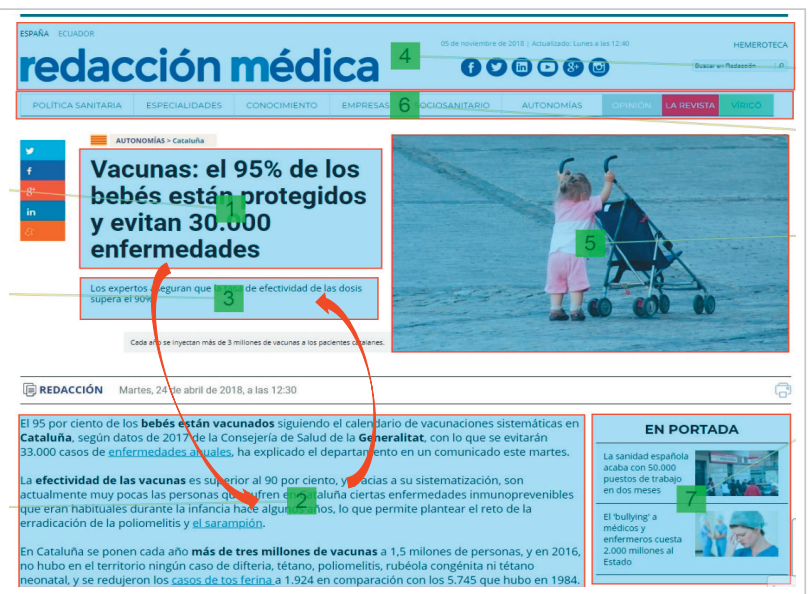

Figure 8. Pro-vaccine gaze path, Women

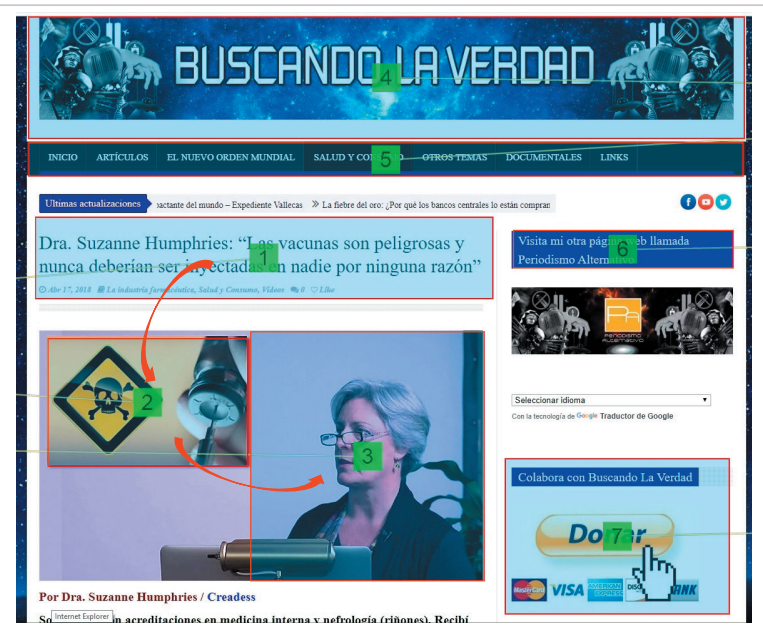

Figure 10. Anti-vaccine gaze path, Women

Finally, we raised the hypothesis that anti-vaccine messages use more emotional content, provoking a greater implicit sentiment, which can be evaluated by GSR and facial expression. Regarding the effect on emotions, the data obtained from the galvanic skin response (GSR) show a similar emotional response in both cases. Although it was fairly higher in the anti-vaccine page ( 6.5 peaks $\left.^{1}\right)$ than in the pro-vaccine one (6.16 peaks), this difference has not been determined to be statistically significant.

However, significant sex-based differences have been found in the "emotion" or engagement aroused in both cases: in the pro-vaccine page, men showed greater arousal (GSR) (7.3 peaks) than women did (4.7 peaks). Meanwhile, the 
anti-vaccine page caused a greater GSR in women $(9.4$ peaks) than in men ( 2.8 peaks).

The data obtained from the facial expression, as already explained, allow us to evaluate (1) the engagement and (2) the facial emotions, offering measures of positive, negative, or neutral "valence" depending on the global mood of the subject and the reactions provoked.
We identified gender differences in visual patterns of web content consumption: women looked at the headlines and then the body of the news, while men looked at the photograph before the text

The resultant engagement was lower in the pro-vaccine

page $(8 \%)$ than in the anti-vaccine page $(10.7 \%)$. The latter also found significant differences between sexes: women showed higher levels of response (16.9\%) than men (4\%).

Analyzing the type of emotion by sexes we see that in the pro-vaccine page, women showed a more negative emotion (3.5\%) than men (0.3\%). However, on the anti-vaccination page, women had a much more positive reaction (5.9\%) than men $(2.8 \%)$.

In brief, according to the results:

- no differences were found in the arousal (GSR), in the emotion, nor in the engagement when the difference between pro- and antivaccine pages were analyzed globally. This deviates from expectations, given that the original hypothesis held that anti-vaccines use messages that mobilize the "limbic resonances" rather than more objective and less emotional messages of the pro-vaccine information sources;

- an interaction effect appears between gender and type of information presented: women seem to present higher levels of arousal, engagement, and positive emotions regarding anti-vaccine messages compared to pro-vaccine pages, whereas men do not present this pattern;

- there are also differences in the visual patterns of information consumption when comparing men and women.

\section{Conclusion and discussion}

\subsection{Speech on vaccines offered by the media on the internet}

The flow of communication about vaccines on websites fluctuates over time, with a steep decline since 2015 but with increased interest in 2018. The number of media platforms talking about vaccines has diversified, making it difficult for those reporting about vaccines to be specialists on the subject. With this increase in information about vaccines, there is a lack of reference sites in relation to information sources; references that would transmit rigor and credibility to the information and that are effective for users (Dubé et al., 2016; Onnela et al., 2016). Within the topic of vaccines, the issues treated in the media have also varied over time. However, there are certain topics for which interest has been maintained over the years, such as for general information, or over the debate on the effectiveness of certain vaccines, which has increased in the last year fueling the social debate. We observed an inefficiency in the dissemination of informational campaign

Men showed greater emotion (tested with galvanic skin response, GSR) with pro-vaccine pages, while women showed much more emotion (GSR) and engagement (facial emotion) with a positive value in anti-vaccine pages regarding side effects or public health policies. The type of vaccine discussed on media platforms also varies depending on seasonal variables and specific news about discoveries or outbreaks. The publication of information on certain vaccines against influenza, HPV, and meningitis has remained steady over time. This phenomenon produces a segmentation of the information in relation to other vaccines causing the reappearance of diseases that were eradicated (the dissemination of powerful anti-vaccine information flows in short periods of time which enhances the effects, causing non-vaccination in certain sectors, which can generate outbreaks of eradicated diseases) (Cepce, 2015; 2018).

\subsection{Pro- and anti-vaccine trends on the Internet and Facebook}

The tone used by the media in websites and digital press towards vaccines usually trends towards being neutral, followed by pro-vaccine. This trend in attitudes changes when attention is directed to social networks. The sparse presence of anti-vaccine news is especially noticeable in recent years. This movement lacks sources of reference, except for Miguel Jara's blog, which centers its activity in social networks such as Facebook and Twitter. These data show the need for training and awareness among specialists to evaluate how useful these platforms are for public health education to help generate confidence in vaccines $(W H O, 2014)$. Facebook groups about vaccines have diversified in recent years, going from an anti-vaccine presence only to also including pro-vaccines or neutral spaces where people share their doubts. However, these spaces lack the presence of specialists and tend to have a negative or fearful tone towards vaccines. These data coincide with those observed by Huesch et al., (2013) and Seeman, Ing and Rizo (2010) who found that Facebook groups about vaccines tended to focus more on harm and risks than on benefits. 
Emphasis is placed on the need for future research on user's behavior in groups affected by infectious diseases, and specialized counseling strategies. In the case of Facebook pages, we observed something interesting: while on a general level there is a greater popularity of pro-vaccine profiles, in the case of Spanish pages this trend varies, the most popular being anti-vaccines, especially the page of Miguel Jara which has maintained popularity over time. This type of space can cause confusion and disinformation (Wilson et al., 2014). Therefore, its identification and monitoring will allow the identification of possible myths surrounding the vaccines.

\subsection{Influencers or digital opinion leaders (DOLs)}

In the case of websites, no media platforms have been identified that stand out especially in the field of vaccines. The most influential media are digital newspapers with health sections, as well as news agencies. Private blogs have little public influence. However, in social networks influencers are clearly identified, which can be classified by their ability to influence (number of followers) and their message (in favor of or against vaccines), especially on Twitter. We see how this network has become important in public health, since in recent years the publication of tweets about vaccines has grown considerably. Due to the nature of social networks, some pro-vaccine DOLs profiles that appeared in 2015 disappeared by 2018. However, we highlight the role of the profiles of the Comité Asesor de Vacunas de la Asociación Española de Pediatría (Vaccine Advisory Committee of the Spanish Pediatric Association, @CAV-AEP) and the Sociedad Española de Pediatría Extrahospitalaria y Atención Primaria (Spanish Society of Outpatient Pediatrics and Primary Care, $@ S E P E A P)$ that remain among the most popular. In the case of anti-vaccine influencers, the presence of relevant profiles is lower; among the most notable are Miguel Jara Blog (@MiguelJaraBlog) and Juan Gervás (@JuanGrvas). The analysis of the influencers shows two common denominators:

- the ability to combine different digital platforms, such as a main web page of a more informative nature, with frequent publications in social networks;

- the importance of constancy in publishing and activity through time, that allows them to remain as references to the constant flow of information and the liquid capacity of digital media.

\subsection{Effects on attention and emotion}

No great differences were noted in the way of looking and structuring the information of the two types of messages. In both cases, the main element is the headline, which contextualizes the frame of the news. Another important element is the header, where the name of the page that provides the information about the source or the website they are visiting appears.

However, there are differences in the way men and women look and consume the available information. Women pay more attention to headlines and bodies of texts, that is to say, to the content. Meanwhile, men first look at texts and then at images, which are more visually attractive and simple to understand. More empirical work on gender differences in the way of looking at and structuring information are needed to understand its possible effects on the cognitive processing of individuals.

Contrary to expectations, no differences were found in the triggered emotion (GSR) between both websites. This variable is important since the hypothesis was raised that anti-vaccine sites would cause a greater implicit sentiment resulting in greater psychophysiological responses. Previous work coincides on the role of this type of message, based on fear and emotion, which results in greater emotional involvement (Lewis; Amini; Lannon, 2001; Millon, 2003) and corresponding attitudes and beliefs (Price; Tewksbury; Powers, 1997; Aday, 2006; Keum et al., 2005). Our results raise a new perspective, where persuasion would not occur as much through the emotional route but over cognitive stimuli. This way, people with determined prior beliefs- take for example beliefs in conspiracy theories- would use the representational heuristic (Tversky; Kahneman, 1974), thus avoiding full reasoning about events that involve uncertainty, probability, and risk. Based on previous thoughts and stereotypes, people would make an illusory correlation of information from incomplete or partial data. In this way, they take as valid non-rigorous information or fakes, using their own representativeness schemes. In the case of false information and vaccines, future research should deepen the role of reasoned motivation and representativeness heuristics to further understand the processing of information and its effect on individuals.

Nevertheless, differences have been found when analyzing sex-based effects. Men showed greater emotion with the pro-vaccine page. On the contrary, women showed much more positive emotion and engagement with the anti-vaccine page. Future works should deepen in the meaning of this emotional response, in order to understand if it is caused because the message awakens true sympathy, or because women don't take these seriously, generating a kind of indirect positive feeling through "irony" rather than acceptance of the message. The way women perceive these messages is extraordinarily important due to the role that women play in public health, because of their high involvement in the health management of their entire family unit (Cuesta-Cambra et al., 2017).

In this sense, this research offers data of great interest on the scenario of public information and communication regarding vaccines; data that can be very useful for the design of future campaigns of communication and intervention on vaccines, health education, and programs of primary prevention in the field of communication and public health. 


\section{Note}

1. The peak consists of the metric used by the algorithm designed by iMotions to evaluate the arousal in terms of skin dermo electric activity. It can be found in:

https://imotions.com/gsr

\section{References}

Ache, Kevin A.; Wallace, Lorraine S. (2008). "Human papillomavirus vaccination coverage on YouTube". American journal of preventive medicine, v. 35, n. 4, pp. 389-392.

https://doi.org/10.1016/j.amepre.2008.06.029

Aday, Sean (2006). "The framesetting effects of news: An experimental test of advocacy versus objectivist frames". Journalism \& mass communication quarterly, v. 83, n. 4, pp 767-784.

https://doi.org/10.1177/107769900608300403

Anderberg, Michael (1973). Cluster analysis for applications. № OAS-TR-73-9. Office of the Assistant for Study Support Kirtland AFB N MEX. ISBN: 9780120576500

https://doi.org/10.1016/C2013-0-06161-0

Añaños-Carrasco, Elena (2015). “La tecnología del 'EyeTracker' en adultos mayores: cómo se atienden y procesan los contenidos integrados de televisión". Comunicar, v. 23, n. 45, pp. 75-83.

https://doi.org/10.3916/C45-2015-08

Betsch, Cornelia; Sachse, Katharina (2013). "Debunking vaccination myths: Strong risk negations can increase perceived vaccination risks". Health psychology, v. 32, n. 2, pp. 146.

https://doi.org/10.1037/a0027387

Browne, Matthew; Thomson, Patricia; Rockloff, Matthew J.; Pennycook, Gordon (2015)." Going against the herd: psychological and cultural factors underlying the 'vaccination confidence gap'". PLoS one, v. 10, n. 9, pp e0132562.

https://doi.org/10.1371/journal.pone.0132562

Cárdaba, Miguel-Ángel; Briñol, Pablo; Brändle, Gaspar; Ruiz-SanRomán, José A. (2016). "The moderating role of aggressiveness in response to campaigns and interventions promoting anti-violence attitudes". Aggressive behavior, v. 42, n. 5, pp. 471-482.

https://doi.org/10.1002/ab.21643

CDC (2013). CDC Telebriefing on the national immunization survey, vaccine for children program, and recent measles outbreaks in the U.S. Press briefing transcript.

https://www.cdc.gov/media/releases/2013/t0912_measles-outbreaks-data.html

Chanel, Olivier; Luchini, Stéphane; Massoni, Sébastien; Vergnaud, Jean-Christophe (2011). "Impact of information on intentions to vaccinate in a potential epidemic: Swine-origin Influenza A (H1N1)". Social science \& medicine, v. 72, n. 2, pp. 142-148.

https://doi.org/10.1016/j.socscimed.2010.11.018

Chen, Zenghao; Koh, Pang-Wei; Ritter, Philip L.; Lorig, Kate; Bantum, Erin-O'Carroll; Saria, Suchi (2015). “Dissecting an online intervention for cancer survivors: Four exploratory analyses of internet engagement and its effects on health status and health behaviors". Health education \& behavior, v. 42, n. 1, pp. 32-45.

https://doi.org/10.1177/1090198114550822

Clauset, Aaron; Newman, Micaleah E. J.; Moore, Cristopher (2004). "Finding community structure in very large networks". Physical review $E$, v. 70, n. 6, 066111.

http://ece-research.unm.edu/ifis/papers/community-moore.pdf

Cuesta-Cambra, Ubaldo (2013). "Fundamentos psicosociales de la reputación online: Propuesta de un modelo y un caso de análisis". Estudios sobre el mensaje periodístico, v. 19, pp. 691-700.

https://core.ac.uk/download/pdf/38814787.pdf

Cuesta-Cambra, Ubaldo; Cuesta-Díaz, Victoria; Gaspar-Herrero, Sandra. (2016). “Vacunas y anti vacunas en la red social Youtube". Opción, v. 32, n. 9.

https://dialnet.unirioja.es/servlet/articulo?codigo $=5891177$

Cuesta-Cambra, Ubaldo; Gaspar-Herrero, Sandra (2014). "La 'reputación online' de la información de vacunas en internet". Historia y comunicación social, v. 19, p. 15.

https://doi.org/10.5209/rev_HICS.2014.v19.45007

Cuesta-Cambra, Ubaldo; Martínez-Martínez, Luz; Niño-González, Jose-Ignacio (2018a). "A case study in neuromarketing: Analysis of the influence of music on advertising effectivenes through eye-tracking, facial emotion and GSR". Euro- 
pean journal of social science education and research, v. 5, n. 2, pp. 84-92.

https://doi.org/10.26417/ejser.v5i2.p84-92

Cuesta-Cambra, Ubaldo; Martínez-Martínez, Luz; Niño-González, José-Ignacio (2018b). “Estrategias y contenidos considerados más eficaces por los jóvenes para la prevención del virus del papiloma humano desde Facebook". Revista cubana de información en ciencias de la salud, v. 29, n. 3.

http://www.medigraphic.com/cgi-bin/new/resumen.cgi?IDARTICULO=83779

Cuesta-Cambra, Ubaldo; Niño-González, José-Ignacio; Rodríguez-Terceño, José (2017). “El procesamiento cognitive en una app educative con electroencefalograma y 'Eye Tracking'”. Comunicar, v. 25, n. 52, pp. 41-50.

https://doi.org/10.3916/C52-2017-04

Cuesta-Cambra, Ubaldo; Peñafiel-Díez, Carmen; Terrón, José-Luis; Bustamante, Edilson; Gaspar-Herrero, Sandra (coords.) (2017). Comunicación y salud. Madrid: Dextra Editorial. ISBN: 9788416898206

Dannetun, Eva; Tegnell, Anders; Hermansson, Göran; Giesecke, Johan (2005). "Parents' reported reasons for avoiding MMR vaccination: A telephone survey". Scandinavian journal of primary health care, v. 23, n. 3, pp. 149-153. https://doi.org/10.1080/02813430510031306

Downs, Julie S.; De-Bruin, Wändi-Bruine; Fischhoff, Baruch (2008). "Parents' vaccination comprehension and decisions". Vaccine, v. 26, n. 12, pp. 1595-1607.

https://doi.org/10.1016/j.vaccine.2008.01.011

Dubé, Eve; Gagnon, Dominique; Zhou, Zhou; Deceuninck, Genevieve (2016). "Parental vaccine hesitancy in Quebec (Canada)". PLoS currents, 7 marzo.

https://doi.org/10.1371/currents.outbreaks.9e239605f4d320c6ad27ce2aea5aaad2

Duchowski, Andrew (2007). Eye tracking methodology. Theory and practice. United Kingdom: Springer London. ISBN: 9781846286087

ECDC (2015a). Seasonal influenza vaccination and antiviral use in Europe. Overview of vaccination recommendations and coverage rates in the EU Member States for the 2013-14 and 2014-15 influenza seasons. Estocolmo: European Centre for Disease Prevention and Control.

http://ecdc.europa.eu/en/publications/Publications/Seasonal-influenza-vaccination-antiviral-use-europe.pdf

ECDC (2015b). Rapid literature review on motivating hesitant population groups in Europe to vaccinate. Estocolmo: European Centre for Disease Prevention and Control. ISBN: 9789291937219

https://ecdc.europa.eu/sites/portal/files/media/en/publications/Publications/vaccination-motivating-hesistantpopulations-europe-literature-review.pdf

ECDC (2018). Monthly measles and rubella monitoring report, January 2018. Estocolmo: European Centre for Disease Prevention and Control.

https://ecdc.europa.eu/sites/portal/files/documents/Monthly\%20meas/es\%20and\%20rubella\%20monitoring\%20 report\%20-\%20JAN\%202018.pdf

Entman, Robert (1993). "Framing: Toward clarification of a fractured paradigm". Journal of communication, v. 43, n. 4, pp 51-58.

https://doi.org/10.1111/j.1460-2466.1993.tb01304.x

Erceg-Hurn, David M.; Steed, Lyndall G. (2011). "Does exposure to cigarette health warnings elicit psychological reactance in smokers?". Journal of applied social psychology, v. 41, n. 1, pp. 219-237.

https://doi.org/10.1111/j.1559-1816.2010.00710.x

Hale, Timothy M.; Pathipati, Akhilesh S.; Zan, Shiyi; Jethwani, Kamal (2014). "Representation of health conditions on Facebook: content analysis and evaluation of user engagement". Journal of medical Internet research, v. 16, n. 8. https://doi.org/10.2196/jmir.3275

Hansen, Derek L.; Shneiderman, Ben; Smith, Marc A. (2010). Analyzing social media networks with NodeXL: Insights from a connected world. Morgan Kaufmann. ISBN: 9780123822297

Horne, Zachary; Powell, Derek; Hummel, John E.; Holyoak, Keith (2015). "Countering antivaccination attitudes". Proceedings of the National Academy of Sciences, v. 112, n. 33, pp. 10321-10324.

https://doi.org/10.1073/pnas.1504019112

Huesch, Marco; Ver-Steeg, Greg; Galstyan, Aram (2013). "Vaccination (anti-) campaigns in social media”. In: Workshops at the Twenty-Seventh AAAI Conference on Artificial Intelligence, pp. 31-34.

https://www.aaai.org/ocs/index.php/WS/AAAIW13/paper/viewFile/7094/6502 
Jones, Abbey M.; Omer, Saad B.; Bednarczyk, Robert A.; Halsey, Neal A.; Moulton, Lawrence H.; Salmon, Daniel A. (2012). "Parents' source of vaccine information and impact on vaccine attitudes, beliefs, and nonmedical exemptions". Advances in preventive medicine, v. 2012.

https://doi.org/10.1155/2012/932741

Kang, Yahui; Cappella, Joseph N.; Fishbein, Martin (2009). "The effect of marijuana scenes in anti-marijuana public service announcements on adolescents' evaluation of ad effectiveness". Health communication, v. 24, n. 6, pp. 483-493. https://doi.org/10.1080/10410230903104269

Kata, Anna (2012). "Anti-vaccine activists, Web 2.0, and the postmodern paradigm - An overview of tactics and tropes used online by the anti-vaccination movement". Vaccine, v. 30, n. 25, pp. 3778-3789.

https://doi.org/10.1016/j.vaccine.2011.11.112

Keelan, Jennifer; Pavri, Vera; Balakrishnan, Ravin; Wilson, Kumanan (2010). "An analysis of the Human Papilloma Virus vaccine debate on MySpace blogs". Vaccine, v. 28, n. 6, pp. 1535-1540.

https://doi.org/10.1016/j.vaccine.2009.11.060

Keum, Heejo; Hillback, Elloit D.; Rojas, Hernando; Gil-De-Zuniga, Homero; Shah, Dhavan V.; Mcleod, Douglas M. (2005). "Personifying the radical: How news framing polarizes security concerns and tolerance judgments". Human communication research, v. 31, n. 3, pp. 337-364.

https://doi.org/10.1111/j.1468-2958.2005.tb00875.x

Kortum, Philip; Edwards, Christine; Richards-Kortum, Rebecca (2008). "The impact of inaccurate Internet health information in a secondary school learning environment". Journal of medical internet research, v. 10, n. 2.

https://doi.org/10.2196/jmir.986

Kuo, Feng-Yang; Hsu, Chiung-Wen; Day, Rong-Fuh (2009). "An exploratory study of cognitive effort involved in decision under Framing - an application of the eye-tracking technology". Decision support systems, v. 48, n. 1, pp. 81-91.

https://doi.org/10.1016/j.dss.2009.06.011

Larson, Heidi J.; De-Figueiredo, Alexandre; Xiahong, Zhao; Schulz, William S.; Verger, Pierre; Johnston, Iain G.; Cook, Alex R.; Jones, Nick S. (2016). "The state of vaccine confidence 2016: global insights through a 67-country survey". EBioMedicine, v. 12, pp. 295-301.

https://doi.org/10.1016/j.ebiom.2016.08.042

Larson, Heidi J.; Jarrett, Caitlin; Eckersberger, Elisabeth; Smith, David M. D.; Paterson, Pauline (2014). “Understanding vaccine hesitancy around vaccines and vaccination from a global perspective: A systematic review of published literature, 2007-2012". Vaccine, v. 32, n. 19, pp. 2150-2159.

https://doi.org/10.1016/j.vaccine.2014.01.081

Lewis, Thomas; Amini, Fari; Lannon, Richard (2001). A general theory of love. Vintage. ISBN: 9780375709227

Liu, Dong; Brown, Bradford (2014). "Self-disclosure on social networking sites, positive feedback, and social capital among Chinese college students". Computers in human ehavior, v. 38, pp. 213-219.

https://doi.org/10.1016/j.chb.2014.06.003

Liu, Fengchen; Enanoria, Wayne T. A.; Zipprich, Jennifer; Blumberg, Seth; Harriman, Kathleen; Ackley, Sarah F.; Wheaton, William D.; Allpress, Justine L.; Porco, Travis C. (2015). "The role of vaccination coverage, individual behaviors, and the public health response in the control of measles epidemics: an agent-based simulation for California". BMC public health, v. 15, n. 1.

https://www.ncbi.nlm.nih.gov/pmc/articles/PMC4438575

https://doi.org/10.1186/s12889-015-1766-6

Love, Brad; Himelboim, Itai; Holton, Avery; Stewart, Kristin (2013). "Twitter as a source of vaccination information: content drivers and what they are saying". American journal of infection control, v. 41, n. 6, pp. 568-570. https://doi.org/10.1016/j.ajic.2012.10.016

Lozares, Carlos (1996). "La teoría de redes sociales". Papers: revista de sociologia, n. 48, pp. 103-126. https://doi.org/10.5565/rev/papers/v48n0.1814

Madurga, Jesús (2018). "Las mejores herramientas de monitorización social media 2018”. NeoAttack. https://neoattack.com/herramientas-para-monitorizar-redes-sociales-e-internet

Martínez-Martínez, Luz; Cuesta-Cambra, Ubaldo (2018). “Conocimiento y actitudes hacia el virus del papiloma humano en una población de universitarios españoles". Revista española de comunicación en salud, v. 9, n. 1, pp. 14-21.

https://doi.org/10.20318/recs.2018.4248 
McCombs, Maxwell E.; Shaw, Donald L. (1972). "The agenda-setting function of mass media”. Public opinion quarterly, v. 36, n. 2, pp. 176-187.

https://doi.org/10.1086/267990

Millon, Theodore; Lerner, Melvin J.; Weiner, Irving (2003). Handbook of psychology: Volume 5. Personality and social psychology. New Jersey: John Wiley \& Sons, Inc. ISBN: 0471384046

http://www.communicationcache.com/uploads/1/0/8/8/10887248/handbook_of_psychology_volume_5_personality_ and_social_psychology_2003.pdf

Nasir, Laeth (2000). "Reconnoitering the antivaccination web sites: news from the front". Journal of family practice, v. 49, n. 8, pp. 731-731.

https://www.mdedge.com/familymedicine/article/60871/vaccines/reconnoitering-antivaccination-web-sites-news-front

Nyhan, Brendan; Reifler, Jason; Richey, Sean; Freed, Gary L. (2014). “Effective messages in vaccine promotion: a randomized trial". Pediatrics, v. 133, n.4.

https://doi.org/10.1542/peds.2013-2365

Onnela, Jukka-Pekka; Landon, Bruce E.; Kahn, Anna-Lea; Ahmed, Danish; Verma, Harish; O'Malley, A. James; Bahl, Sunil; Sytter, Roland W.; Christakis, Nichilas A. (2016). "Polio vaccine hesitancy in the networks and neighborhoods of Malegaon, India". Social science \& medicine, v. 153, p. 99-106.

https://doi.org/10.1016/j.socscimed.2016.01.024

Peña-Lillo-Arayasa, Macarena-Sofía (2016). "Hábitos de búsqueda y escaneo de información sobre salud en adultos Chilenos". Revista de comunicación y salud, v. 6, p. 28-41.

https://dialnet.unirioja.es/servlet/articulo?codigo $=5786974$

Plassmann, Hilke; Ramsøy, Thomas-Zoëga; Milosavljevic, Milica (2012). "Branding the brain: A critical review and outlook". Journal of consumer psychology, v. 22, n. 1, pp. 18-36.

https://doi.org/10.1016/j.jcps.2011.11.010

Preece, Jennifer; Shneiderman, Ben (2009). "The reader-to-leader framework: Motivating technology-mediated social participation". AlS transactions on human-computer interaction, v. 1, n. 1, pp. 13-32.

https://aisel.aisnet.org/thci/vol1/iss1/5

Price, Vicent; Tewksbury, David; Powers, Elizabeth (1997). "Switching trains of thought: The impact of news frames on readers' cognitive responses". Communication research, v. 24, n. 5, pp. 481-506.

https://doi.org/10.1177/009365097024005002

Rus, Holly M.; Cameron, Linda D. (2016). "Health communication in social media: Message features predicting user engagement on diabetes-related Facebook pages". Annals of behavioral medicine, v. 50, n. 5, pp. 678-689.

https://doi.org/10.1007/s12160-016-9793-9

Salathé, Marcel; Bonhoeffer, Sebastian (2008). "The effect of opinion clustering on disease outbreaks". Journal of The Royal Society Interface, v. 5, n. 29, pp. 1505-1508.

https://doi.org/10.1098/rsif.2008.0271

Scheufele, Dietram A. (1999). "Framing as a theory of media effects". Journal of communication, v. 49, n. 1, pp 103-122. https://doi.org/10.1111/j.1460-2466.1999.tb02784.x

Seeman, Neil; Ing, Alton; Rizo, Carlos (2010). "Assessing and responding in real time to online anti-vaccine sentiment during a flu pandemic". Healthc $Q$, v. 13, pp 8-15.

https://pdfs.semanticscholar.org/9208/4972868125d3d552d1e60151eb7a32c881e4.pdf

Syred, Jonathan; Naidoo, Carla; Woodhall, Sarah; Baraitser, Paula (2014). "Would you tell everyone this? Facebook conversations as health promotion interventions". Journal of medical internet research, v. 16, n.4.

https://doi.org/10.2196/jmir.3231

Turcotte, Jason; York, Chance; Irving, Jacob; Scholl, Rosanne; Pingree, Raymond J. (2015). "News recommendations from social media opinion leaders: Effects on media trust and information seeking". Journal of computer-mediated communication, v. 20, n. 5, pp 520-535.

https://doi.org/10.1111/jcc4.12127

Tversky, Amos; Kahneman, Daniel (1974). “Judgment under uncertainty: Heuristics and biases”. Science, v. 185, n. 4157, pp. 1124-1131.

https://doi.org/10.1126/science.185.4157.1124

Tversky Amos; Kahneman Daniel (1981). "The framing of decisions and the psychology of choice”. Science, v.2 11, n. 4481; pp. 453-458.

https://doi.org/10.1126/science. 7455683 
Veale, Hilary J.; Sacks-Davis, Rachel; Weaver, Emma R. N.; Pedrana, Alisa E.; Stoové, Mark A.; Hellard, Margaret E. (2015). "The use of social networking platforms for sexual health promotion: identifying key strategies for successful user engagement". BMC public health, v. 15, n. 1, pp 85.

https://www.ncbi.n/m.nih.gov/pmc/articles/PMC4340797

https://doi.org/10.1186/s12889-015-1396-z

Verger, Pierre; Fressard, Lisa; Collange, Fanny; Gautier, Arnaud; Jestin, Christine; Launay, Odile; Raude, Jocelyn; Pulcini, Céline; Peretti-Watel, Pulcini (2015). "Vaccine hesitancy among general practitioners and its determinants during controversies: A national cross-sectional survey in France". EBioMedicine, v. 2, n. 8, pp. 891-897.

https://doi.org/10.1016/j.ebiom.2015.06.018

Wang, Ruoxo; Kim, Jinyoung; Xiao, Anli; Jung, Yong-Ju (2017). “Networked narratives on humans of New York: A content analysis of social media engagement on Facebook". Computers in human behavior, v. 66, pp. 149-153.

https://doi.org/10.1016/j.chb.2016.09.042

WHO (2014). Report of the SAGE working group on vaccine hesitancy. World Health Organization.

http://www.who.int/immunization/sage/meetings/2014/october/1_Report_WORKING_GROUP_vaccine_hesitancy_ final.pdf

Williams, Hywel T. P.; McMurray, James R.; Kurz, Tim; Lambert, F. Hugo (2015). "Network analysis reveals open forums and echo chambers in social media discussions of climate change". Global environmental change, v. 32, pp. $126-138$.

https://doi.org/10.1016/j.gloenvcha.2015.03.006

Wilson, Kumanan; Atkinson, Katherine; Deeks, Shelley (2014). “Opportunities for utilizing new technologies to increase vaccine confidence". Expert review of vaccines, v. 13, n. 8, pp. 969-977.

https://doi.org/10.1586/14760584.2014.928208

Witteman, Holly O.; Zikmund-Fisher, Brian J. (2012). "The defining characteristics of Web 2.0 and their potential influence in the online vaccination debate". Vaccine, v. 30, n. 25, pp. 3734-3740.

https://doi.org/10.1016/j.vaccine.2011.12.039

Wong, Charlene A.; Merchant, Raina M.; Moreno, Megan A. (2014). “Using social media to engage adolescents and young adults with their health". Healthcare, v. 2, n. 4, pp. 220-224.

https://doi.org/10.1016/j.hjdsi.2014.10.005

Zimmerman, Richard K.; Wolfe, Robert M.; Fox, Dwight E.; Fox, Jake R.; Nowalk, Mary-Patricia; Troy, Judith A.; Sharp, Lisa K. (2005). "Vaccine criticism on the world wide web". Journal of medical internet research, v. 7, n. 2.

https://doi.org/10.2196/jmir.7.2.e17

\section{Da visibilidad a tu trabajo depositándolo en e-LIS, el mayor repositorio internacional sobre biblioteconomía, documentación y comunicación}

\section{ent information science}

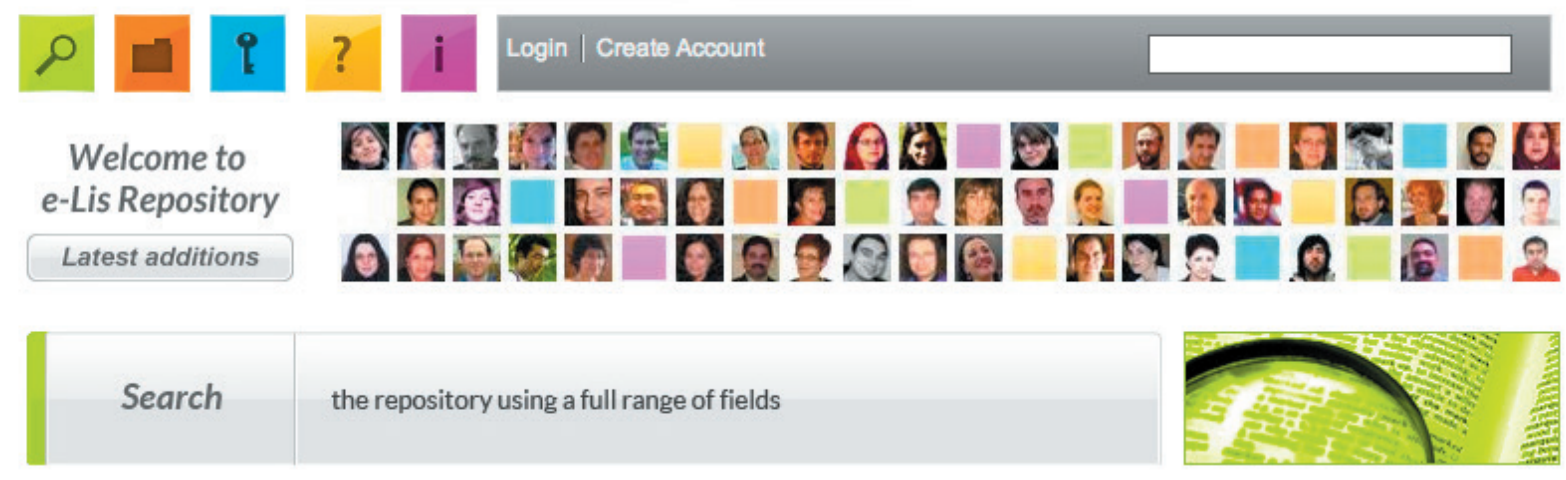

http://eprints.rclis.org 